\title{
Clients Experiences on a Government Higher Education Institution Frontline Services
}

\author{
Marlow T. Pacapac
}

\begin{abstract}
The study present the clients' experiences on the different frontline services provided by one government run higher education institution (HEI) in Ilocos Sur, Philippines. It employed a descriptive survey research design utilizing qualitative approach with a self-structured survey instrument. The participants of the study were graduates of the HEI under study. The participants were selected thru purposive sampling. Findings of the study reveals that the Higher Education Institution In Ilocos Sur under study is efficient in the delivery of services and provides satisfactory service to its clientele. However attitudinal problem on some frontline service personnel and poor records handling of some frontline service offices of the HEI needs re-assessment to take necessary measure to address the issues. It is recommended that the management should consider the problems observed and should take necessary mechanisms to improve the satisfaction to its clientele, particularly on for the personnel, reorientation and reflection for development in their attitudes, skills and total personality focusing on clients delight and satisfaction may be undertaken; and systematic records keeping and updating of documents must be undertaken by the frontline service offices.
\end{abstract}

Keywords:- Client Experience, Frontline Services, Higher Education Institution.

\section{INTRODUCTION}

Government agencies are always visited by the citizens to transact businesses and utilize services, requests for issuance of documents and other important matters. The government is established for its citizens, to protect and to promote the general welfare and rights of the public(Pañares and Abocejo, 2019). It works for the good of its citizens without any purpose to abuse power (Evangelio and Abocejo, 2015) and personal gain. Given the crucial role of the government, one who is working and paid by the estate must have the heart for the people (Andaya and Abocejo, 2019), passion to serve and high sense of accountability.

Using frontline services, those concerning direct contact between citizens and public servants, had long been a root of frustration among citizens in the Philippines. Procedures were ordinary unnecessarily complex, and even when they were not, some Filipinos knew precisely how to get the necessary services they needed. To get a business permit, a driver's license, or a birth certificate, Filipinos oftentimes had to wait for hours in cramped, unventilated offices that had lacking of seats. When their numbers finally were called, many learned that their requests required additional approvals or supplementary documentation from other officials in the agency-or other parts of the government.(Maya Gainer 2014)

On a statement by Bacal (2005) as cited by Perez (2019), noted that fast and prompt services are of important concern of customers. They want the serving personnel to make efforts and assist them effectively and efficiently. Clients also expect that servicing personnel are not creating conditions and excuses which cause the wait longer than appropriate. A frontline staff must do all efforts to ease clients' requests the soonest possible time.

This goal of the government is deeply intensified through the passage into law of Republic Act No. 6713 (Code of Conduct and Ethical Standards for Public Officials and Employees) and Republic Act No. 9485 (Anti-Red Tape Act of 2007" -ARTA) whose main goal is to improve the effectiveness and efficacy in delivering government services by way of molding out bureaucratic red tape and the strict processes that slow down the processing of certain transaction thereby stop graft activities in all government and public institutions.

Exposure to government agencies is inevitable. Nonetheless, almost all entrepreneurs frequently find it frustrating to transact with government agencies due to bureaucratic red tape, corruption and slow delivery of services.

According to Torres (2016) as cited by Andres (2019), University's performance requires the commitment of administration, faculty, and staff for the continued quality improvement in all aspects associated with the accomplishment of the University's mission. To guarantee success, we need to ask ourselves the following: (1) What do we need to accomplish? (2) Are we doing it as well as we need? (3) How do we see if we are succeeding? and (4) by what way can we change what we are doing? So, all employee's cooperation must be integrated in order to harmoniously serve the clients; specifically, in the frontline services.

Universities should have a good front line service and encourage all the employees to work hand in hand for the sustainability of quality services to be bestowed to clients and all the people concerned. It is indeed essential to set up good relationship in dealing with the clients that would contribute to an effective institutional performance. As a government line agency and a service provider, the 
university capitalizes on achieving a changing administrative system focused on onward efficiency and effectiveness in government service. For many years, it follow through to the mandate and orders from the Civil Service Commission to fast track the addressing of the need of the dynamic times. The idea provided by the Civil Service Commission in the execution of the new Strategic Performance Management System (SPMS) in reassuring efficient and effective of government service delivery served as the cornerstone of teaching and learning with the attainment of quality, effectiveness and timeliness as the core of its activities. (Andres, 2019)

The endeavor of the government in rigorously monitoring the compliance on existing laws and regulations to improve frontline services delivery is through to all government institutions including higher education institutions (HEIs) particularly the state universities and colleges (SUCs). The Civil Service Commission (CSC) of the Philippines tightly monitor the SUCs as far as service delivery and client contentment are concerned since they provide to the general public and the students.

Aiming for excellence does not only mean being exceptional in instruction, research and extension but also in administrative services. Accordingly, the administrative and support staff play significant roles due to the advancement in communication and information technology with the birth of an 'enterprise culture' within the higher education sphere. Sepitula (2010) stated that aside from the premier mandate of rendering instruction, research and extension to the public, government HEI are necessary instruments in supplying service quality to clients. Mengesha (2015) argued that an accomplishment of any institution relies on the competence of fore employees as they are considered the main characters to build the first and lasting impressions towards an organization's positive image to its clients.

Thus, this study was conducted to present the actual experiences of clients during their transaction on the frontline services of the Higher Education under study. Furthermore, the study would be significant to the employees of the institution under study for the improvement of their services which adheres to the need of their clients.

\section{* Rationale}

This study would attempt to extract the real experience of the clients as far as frontline service delivery is concerned in the HEI under study. The study findings can provide open avenues for improvement in the way services are delivered by the different offices of the HEI to lessen the complaints from the clients.

\section{* Objective}

This study present the experiences of the participant on the frontline services provided by one government Higher Education Institution (HEI) in Ilocos Sur, Philippines.

\section{* Statement of the Problem}

This study aims to present the experiences of the clients on the frontline service of one government run Higher Education Institution in Ilocos Sur. It is for this reason the following questions are forwarded:

1. What are the experiences of the clients during the transaction on the frontline services of one government Higher Education Institution in Ilocos Sur?

2. What are the problems encountered by the clients during the transaction on the frontline services of one government Higher Education Institution in Ilocos Sur?

\section{* Definition of Terms}

Client - are defined as stakeholders in any activity in which the University is engaged. This may include students, alumni,staff, members of the community, and government agencies.

$>$ Experiences - as used in this study pertains to the real sentiments of the clients as far as frontline service delivery is concerned in the HEI under study.

$>$ Frontline Service-as use in this study refers to the process or transaction between clients and University employees involving applications for any privilege, right, permit, reward, license, concession, or for any modification, renewal or extension of the enumerated applications and/or requests which are acted upon in the ordinary course of business of the office concerned.

> Higher Education Institution - any of various types of education given in postsecondary institutions of learning and usually affording, at the end of a course of study, a named degree, diploma, or certificate of higher studies. Higher-educational institutions include not only universities and colleges but also various professional schools that provide preparation in such fields as law, theology, medicine, business, music, and art.

> Problem- as used in this study it pertains to a matter or situation regarded as unwelcome and needing to be dealt with and overcome.

\section{SCOPE AND LIMITATION}

This paper is limited to the experiences and problems encountered by the clients of one government run Higher Education Institution in Ilocos Sur during their transaction of different frontline services.

* Conceptual Framework

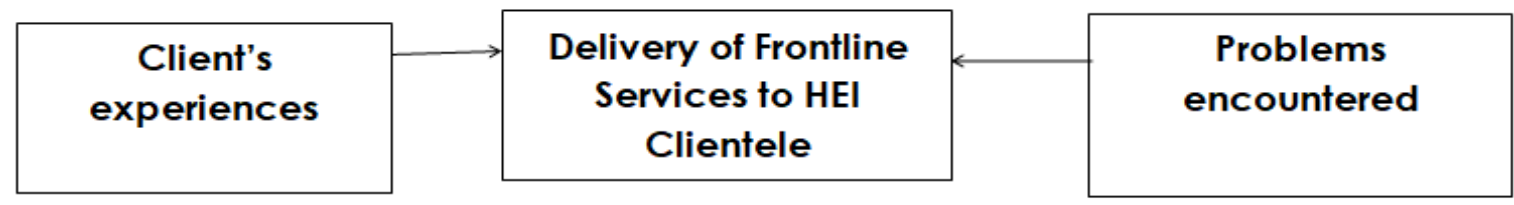

Fig 1:- Research Paradigm 
This conceptual framework shows the clients experiences and problems encountered on the delivery of frontline services of the Higher Education Institution under study.

\section{RESEARCH DESIGN AND METHODOLOGY}

\section{$>$ Research Design}

The study employed a descriptive survey method with qualitative research method using the case study approach.The study used in-depth interviews, which was conducted with graduates of one government run Higher Education Institution in Ilocos Sur under study as the participants. The use of in-depth interviews was regarded as appropriate for the purposes of the study because these allowed for detailed insights into the experiences of the participants by allowing the participants to articulate these experiences in their own words. The use of the unstructured interview guide help to ensure that the interviews remained within the parameters of the study.

\section{Participants}

The participants of the study was 10 graduates of Higher Education Institution under study. The participants was selected thru purposive sampling.

\section{$>$ Instrument}

Semi-structured questionnaire was utilized in exploring the experiences and problems encountered by the participants during their transaction on the frontline services of the Higher Education Institution under study.

\section{$>$ Data Analysis}

The data gathered were analyzed thematically. The recorded interview was transcribed. The transcripts was read over a number of times. Initial notes was listed and emergent themes was identified. The first emergent themes then listed and the researchers try to see the connections of each themes and may be clustered which later may become the superordinate concepts. The themes was translated into a narrative account which expanded and explain the emerged themes.

\section{RESULT \& DISUSSION}

The following shows the responses derived from the participants with regards to their distinctive experiences on the frontline services of the Higher Education Institution under study. Only those statements that seem to have heavier weights in terms of substantiating and validating the derived selected from the verbatim of the participants.

\section{The experiences of the clients during the transaction on the frontline services}

The themes that arises from the responses of the ten participants provides understanding regarding their experiences on the frontline services of the higher education institution under study. The patterns that emerged are presented in two major themes: Efficient delivery of services and Satisfactory Services. Each common theme attempts to accurately present the experiences of the participants.
Efficient delivery of services, this theme explained by majority of participants experiences on the frontline services of the HEI under study. Seven (7) out of the ten (10) participants revealed that they have fast transaction on the offices of university providing frontline services to students. This is evident on the responses of the participants wherein immediate response to concerns as well as right away issuance of the school documents requested by the participants.

Participant 3 stated that: "I've seen how the registrar and cashier facilitates time for faster transactions during enrolment time where bunch of students line up from different colleges". The fast delivery of services is a must on all government agencies in accordance to the objective of Republic Act No. 9485 also named as the "Anti-Red Tape Act of 2007".wherein it is stated in the opening paragraph" to improve the efficiency and delivery of government services to the public by reducing bureaucratic red tape and preventing graft and corruption. Similarly, the study, commissioned by the Integrity for Investments Initiative and USAID Philippines, further stated that the ARTA RCS keeps frontline employees on their toes, and they do their best to comply with the posted standards and ensure fast delivery of service.(CSC,2018)

Furthermore, Participant 7 stressed out that "Even though the different offices of the university caters the needs of students coming from different colleges still facilitates fast transaction during enrollment". Finally, responses of Participant 4, 8, 9 agree that their needs and concerns were directly processed and addressed by the concerned offices.

Satisfactory services, this theme arise from the response of the three other participants in the study. Participant 2 disclosed that, "My experience to the frontline services of the University is great because Despite of too many enrollee still they control and provide the best services for us student". Satisfactory services is goal of any government offices because it what is expected and due to various enactment and reasons. Another reason for satisfactory services of government frontline offices is because of the Strategic Performance Management System,a mechanism that links employee performance with organizational performance to enhance the performance orientation of the compensation system. It ensures that the employee achieves the objectives set by the organization and the organization, on the other hand, achieves the objectives that it has set as its strategic plan. It is linked to the Performance-Based Incentive System (PBIS) that consists of the Productivity Enhancement Incentive (PEI) and the Performance-Based Bonus (PBB). Furthermore, Bejou (2005),Just as taking good care of customers typically results in increased profitability for businesses, higher education institutions that seek to attract and retain their customers (i.e. students) would be well served to also treat their customers well. The advantages of this approach include increased customer satisfaction and loyalty. Taking care of customers should lead to increased retention, which is an increasingly important revenue source for higher education institutions. 
Another participant (Participant 5) revealed that his experience on the services of the university is good enough because policy of the University is strictly implemented. The last participant (Participant 6), stated that the frontline services of the University is satisfactory because it is accessible and students concerns were address.

\section{Problems encountered by the clients during the transaction on the frontline services}

The themes that arises from the responses of the ten participants reveals the problems encountered by them during their transaction to the frontlines services of the higher education institution under study. The patterns that come out are presented in two major themes: Attitudinal problem of some Personnel and Poor Records handling of some offices. Each common theme try to accurately present the problems encountered by the participants.

Common problems encountered among the eight (8) out of ten (10) participants during their transaction to the frontline services of the higher education institution under study is the attitudinal problem that some of the personnel of different frontline offices were showing when transacting to their clients. Most of the participants stress out their negative feelings to some personnel of the frontline service offices who showed to them unpleasant manner just like being hot heated or angry when approach, snob and not patient enough. Participant 4 recounted his encounter to one employee: "The only problem that $i$ was encountered from their services not all but some of them are the attitude of their personnel, Example if $i$ am requesting for some documents they looks like murmuring first before they give the requested documents". The attitudinal problem of some employees on government offices just like a government run Higher Education Institution frontline offices is due to the reality that they are serving a large number of clients every having different concerns. These attitudes of some employee is contrary to what is to be expected from a public official or employee. They have taken for granted that they are a public employee and forget their accountability as a public officer or employee as stipulated under Article XI, section 1 of the 1987 Constitution which states that: Public office is a public trust. Public officers and employees must, at all times, be accountable to the people, serve them with utmost responsibility, integrity, loyalty, and efficiency; act with patriotism and justice, and lead modest lives. Their action post a negative effect to the office and to costumer services. Similarly, Kandampully(2001) stated that, since front-line staff is ultimately responsible for what transpires during the customer contact interface, they are the vital link to ensuring what is deemed by the customer to be service satisfaction. Consumers' perceptions of their experience play a major role in determining customer satisfaction and future purchase decisions.Furthermore, Anderson (2011) mentioned that a poor attitude and sense of amateurism can have a negative effect on customer services.
Another participant (Participant 7) revealed that "Some of the staffs tends to become snob, sometimes they talk to you in an angry manner".

Two out of the ten participants brought out the problems they encounter during their transaction to the frontline services of the higher education institution under study was the poor record handling of some frontline service office. Participant 1, disclosed that, "The most common problem that $i$ had encountered from the different offices in the University is with regards to the improper filing of documents or improper keeping of documents some documents submitted to their office were not kept properly that every now and then they will be repetitively asking for a copy of such documents which was already been submitted".Poor handling of documents in schools especially in Higher Education institution is very critical for schools especially documents concerning students performance and academic achievement. Once students records or documents were lost that would result to waste of time and resources for the effort in replacing or reproducing the lost document or record. This will also reflect to the office concern their records management system. According to Amanchukwu RN et. al, (2015) they concluded that poor records management results in difficulties in administering, development and supervision of educational systems. Similarly, Neil Kokemuller, stated that without a proper records management system, you begin to see excessive clutter and a disorganized environment. Additionally, an inefficient records management system makes it very difficult for employees to keep track of customer information and inventory.

Overall the findings of the study reveals that the Higher Education Institution In Ilocos Sur under study is efficient in the delivery of services and provides satisfactory service to its clientele. However attitudinal problem on some frontline service personnel and poor records handling of some frontline service offices of the HEI needs re-assessment to take necessary measure to address the issues.

\section{CONCLUSION}

The government Higher Education Institution managed to deliver good quality of frontline services to its clientele but with some issues on some frontline service personnel and offices which needs necessary mechanism to improve the experiences of its clients.

\section{RECOMMENDATION}

Based on the conclusions drawn the following recommendations are forwarded:

1. For the personnel, reorientation and reflection for development in their attitudes, skills and total personality focusing on clients delight and satisfaction may be undertaken; and

2. Systematic records keeping and updating of documents must be undertaken by the frontline service offices. 
ISSN No:-2456-2165

\section{REFERENCES}

[1]. AmanchukwuR N et. al., (2015) Excellent School Records Behaviour for Effective Management of Educational Systems retrieved from http://article.sapub.org/10.5923.j.hrmr.20150501.02.ht $\mathrm{ml}$ retrieved on August 17, 2020.

[2]. Andaya, J. A. G., \& Abocejo, F. T. (2019). Implementation of the full disclosure policy (FDP) of Basay municipality, Negros Oriental,Philippines: Status, challenges and sustainability. International Journal of Development and Sustainability (IJDS). 8(7), 404-421. Retrieved from https://isdsnet.com/ijds-v8n7-02.pdf.

[3]. Andres ,J. (2019). Performance of the Frontline Employees of the Sucs in Region Ii retrieved from https://www.ijitee.org/wp-content/uploads/papers/v8i6 s3/F10130486S319.pd f retrieved on August 17, 2020

[4]. Bacal, R. (2005). Perfect phrases for customer service. Hundreds of tools, techniques and scripts for handling any situation. McGraw-Hill Companies.

[5]. Bejou, D. (2005, March/April). Treating students like customers. Biz Ed Magazine. Retrievedfrom https://bized.aacsb.edu/articles/2005/march/treating-stu dents-like-customers retrieved on August 11, 2020

[6]. CSC, 2018, New law promises faster, more convenient gov't transactions-CSC retrieved from http://web.csc.gov.ph/new-updates/1561-new-law-pro mises-faster,-more-convenient-govt-transactions\%E2 $\% 80 \% 94 \mathrm{csc}$.html retrieved on August 10,2020

[7]. Mamo G. S. (2018). Assessment of the factors that affect customer satisfaction on servicequality: A case study in Ethio Telecom Dawro Zone. Arabian Journal Business Management Review. 8(1), 1-5. Retrieved from

https://www.omicsonline.org/open-access/assessmentof-the-factors-that-af fect-customer-satisfaction-on service-qualitya-case-study-in-ethio-telecom-dawro-zo ne.pdf.

[8]. Maya G. (2014).LISTENING TO THE PUBLIC: A CITIZEN SCORECARD IN THE PHILIPPINES, 2010-2014 retrieved from https://successfulsocieties.princeton.edu/sites/successf ulsocieties/

files/MG_SocialNorms_Philippines.pdfretrieved on August 17, 2020

[9]. Neil Kokemuller, ND, Symptoms of Poor Record Management retrieved from https://smallbusiness.chron.com/symptoms-poor-recor d-management-4186 4.html retrieved on August 11,2020

[10]. Park, S. \& Hwang, D. (2010). An analysis of policy satisfaction using the expectancy disconfirmation model. The Korean Journal of Policy Studies, 25(3), 47-67. Retrieved from http://s-space.snu.ac.kr/bitstream/10371/73200/1/1t700 331.pdf.

[11]. Perez M et. al. (2019). CLIENTS' SATISFACTION ON THE FRONTLINE SERVICES OF A GOVERNMENT HIGHER EDUCATION
INSTITUTION retrieved from https://oapub.org/edu/index.php/ejes/article/view/ 2801retrieved on July 20, 2020

[12]. RA 9485, retrieved fromhttps://www.officialgazette.gov.ph/2007/06/02/re public-act-no-9485/

[13]. RA 6713, retrieved from https://lawphil.net/statutes/repacts/ra1989/ra_671 3_1989.html

[14]. Sepitula, B. (2010). The role of Philippine state universities in enhancing food security. Journal of International Society for Southeast Asian Agricultural Sciences, 25(2), 18-21. Retrieved from https://pdfs.semanticscholar.org/bfc2/f6db82c0147c6c d0dbdc8f8adbf1def 68bd5. pdf.

[15]. Torres, R.G. (2016) Effectiveness of Frontline Services of Isabela State University System. 